\title{
Assessing Jurisdiction in Electronic-Commerce Disputes Resolution: A Review of the Legal Practice in the United State
}

\author{
Palmer Prince Dagadu* \\ $\mathrm{PhD}$ Candidate in international Law, School of Law, Xiamen University, China. \\ Rita Mawufemor Tsorme \\ Master in Civil and Commercial Law, School of Law, Xiamen University, China.
}

\begin{abstract}
The worldwide and decentralized characteristics of the internet and the open manner at which it operates gives E-commerce a global element which brings about the all-important question of which court has the jurisdiction to resolve disputes in E-commerce transactions. The sharing of state's jurisdiction with regard to international commercial contracts has been on the use of contact factors generally of a territorial nature. The exclusive nature of the internet as a modern phenomenon sometimes makes it difficult to apply these rules. This may make them not legally binding or lead to results that are not favorable or totally alien to the contracting parties and the subject matter of the cases. This study critically examines and review the current legal administrative approach of the United State with regard to assessing jurisdiction in E-commerce disputes resolution. It also analyzes the defects of the legal practice in the US and the postulation of new ideas in assessing and enforcing jurisdiction in E-commerce disputes resolution.
\end{abstract}

Keywords: Electronic Commerce, Assessing Jurisdiction, Disputes Resolution, the US.

DOI: $10.7176 / J L P G / 83-13$

Publication date:March $31^{\text {st }} 2019$

\section{Introduction}

Practically, the most appropriate way to resolve the issue of assessing jurisdiction in E-commerce disputes resolution is the use of choice of jurisdiction and decision of law clauses in electronic contracts as a means for consenting to an agreed jurisdiction and choice of law instead of abandoning it to the vulnerabilities of geologically arranged clash of laws administrations.

Since organizations in the U.S are at the bleeding edge of internet headway, disputes adjudication with regards to E-commerce in the U.S is far developed than anyplace else. The two essential tests the U.S. courts have utilized as part of assessing jurisdictional issues in E-commerce disputes are the milestone cases International Shoe Co. v. Washington and Zippo Manufacturing v Zippo Dot Com Inc. The International Shoe Co. v. Washington case, ${ }^{1}$ which showed that the minimum contacts ${ }^{2}$ test has both a general and a specific segment. ${ }^{3}$

In this case, the Court made a significant stride toward this path and made the 'minimum contacts' test that takes into account jurisdiction over a non-resident when such contacts exist between the defendant and the forum State. This is to such an extent "upkeep of the litigation does not offend "conventional thoughts of reasonable play and considerable equity'." The Court's 'minimum contacts' test for specific jurisdiction ${ }^{4}$ surrender more formalistic tests that emphasis a defendant's 'presence' within a State for a more adaptable investigation into whether a defendant's contacts with the forum made it sensible. This is done with regards to the US federal system of government and expect it to safeguard the suit in that State.

Through cases like International Shoe, the court set out underlying principles in which the States must work in E-commerce disputes. The language in the court's supposition took into account adaptability and a measure of decency under the law. However, it has expelled the sureness and consistency that can just exist under a splendid line run the show.

The second approach known as "Zippo continuum," to determining the jurisdiction of E-commerce disputes was sketched out in the US case of Zippo Manufacturing v Zippo Dot Com Inc. In the Zippo case, the Western Pennsylvania District Court developed the International Shoe "minimum contact test" by expressing that personal jurisdiction for online commercial business disputes ought to be managed on a "sliding scale". ${ }^{5}$ For this this situation, the court-connected a passive versus active test to the question of jurisdiction which included a

\footnotetext{
1326 U.S. 310 (1945).

2"minimum contacts" are a requirement that must be satisfied before a defendant can be sued in a state such as having some connection with with the state in question.

${ }^{3}$ Scoles, Hay, Borchers \& Symeonides (2000), p.344.

${ }^{4}$ Specific jurisdiction is the exercise of personal jurisdiction over a non-resident when the case stems directly from the contacts the party has has with the forum state.

5 See Zippo Mfg. Co. v. Zippo Dot Com, Inc., 952 F. Supp. 1119 (W. D. pa 1997), at 1124.
} 
'sliding scale examination's figuring the nature of the business movement of the defendant online. To assess jurisdiction, the Zippo test requires an interactive site and business activity. The passive versus active approach has been reprimanded for demoralizing interactivity in a period when websites are in certainty ending up more interactive.

\section{Legal Practice to Assess Jurisdiction in E-Commerce Disputes Resolution in the US}

Perhaps because of the fact that organizations in the U.S are at the bleeding edge of internet headway, disputes adjudication with respect to E-commerce is far developed than any other place. The two case laws adopted by the U.S. for E-commerce disputes resolution are General and Specific jurisdiction. The notion above originates from the memorable case, International Shoe Co. v. Washington ${ }^{1}$, which demonstrated that both the general and specific elements are included in the minimum contacts test. ${ }^{2}$ Minimum contacts are a prerequisite that should be fulfilled before a party to an E-commerce dispute can be subjected to litigation in a specific state. All together for the litigation to go ahead in the state decided on, the plaintiff should have a few associations with the state in question. An example includes, marketing or operating inside a state might give minimum contacts between an organization and the country.

\subsection{General Jurisdiction}

According to the regularly utilized minimum contacts, general jurisdiction is typically introduced as "constant and efficient" agreements between the defendant and the forum in order to make the defendant comply to jurisdiction without regard to the nature of the disputes among the parties. ${ }^{3}$ However, contacts that are irrelevant to the disputes will meet the edge of being "constant and efficient", the defendant will comply with general jurisdiction in view of its agreements with the state. One of the troublesome subject matter in connection with general jurisdiction is the quantity of measurement of irrelevant contact agreement expected to bring a defendant to personam jurisdiction. ${ }^{4}$ This means that there should be a continuous physical presence in the forum by the defendant at least in the form of offices. There is an inquiry whether "unimportant" home, instead of habitual or nationality can be an adequate association for the activity of general jurisdiction over the defendant. ${ }^{5}$ The expression that talks about the defendant domicile as being adequate concerning the activity of general jurisdiction is expressed in the Second Restatement. However, this can be absurd if the relationship between the individual and the state is lessened. ${ }^{6}$ Parties consistent, systematic and ongoing connections to a specific forum are as a result of general jurisdiction. ${ }^{7}$

\subsection{Specific Jurisdiction}

In any case, specific jurisdiction involves the nature of the disputes. Thus, if the agreement is related to a purpose for the activity. ${ }^{8}$ It is consistently used when a party's activities could not fulfill the general jurisdiction standard and licenses the assessing of jurisdiction of disputes emerging from the contractual relation by the parties with regards to their activities with the forum being referred to. ${ }^{9}$ Because of the necessity which implies the activities have a line with the dispute, those activities will do the trick for the jurisdiction that comes with the current litigation but not in the litigation identifying with the activities of the defendant in a different state. ${ }^{10}$ Subsequently, deciding if there is specific jurisdiction in a specific issue comes with two different consideration. The initial stage is to find out if the activities are linked to the dispute. Then secondly, to find out if the activities are " fundamental adequate". ${ }^{11}$

Previously, U.S courts had a lot of problems with personal jurisdiction with regards to online business activities. In adjudicating over these litigations, the courts in the U.S hesitatingly see the overall accessibility as a "minimum contract" with reference to a website to adequately build up a particular individual jurisdiction on the non-occupant defendant if there is a different agreement among the parties. ${ }^{12}$

Regardless of if the defendant can be liable to specific jurisdiction in commercial agreement cases relies upon the whole course of managing, including "prior arrangement and considered future consequences"

\footnotetext{
1 International Shoe Co. v. Washington 326 U.S. 310 (1945).

${ }^{2}$ Scoles, Hay, Borchers \& Symeonides (2000), p.344

International Shoe, 326 U.S. at 320, 4

${ }^{4}$ Scoles, Hay, Borchers \& Symeonides (2000), p.348

${ }^{5}$ Ibid.

${ }^{6}$ Restatement, Second, Conflict of Laws $§ 30$ (1971)

Helicopteros Nacionales de Colombia, S.A. v. Hall, 466 U.S.408 (1984).

${ }^{8}$ Ibid

${ }^{9}$ Ashi Metal Ind. Co. v. Superior Court, 480 U.S. 102 (1987).

${ }^{10}$ Maloney (1993), p.1265, $1269-70$.

${ }^{11}$ Scoles, Hay, Borchers \& Symeonides (2000), p.344

${ }^{12}$ Smith, G. J. H. (2002), p.347.
} 
establishing that "the defendant intentionally established minimum contacts with the forum." ${ }^{1}$

Practically speaking, the Courts in U.S came out with two distinctive approaches endeavoring to decide if it has jurisdiction on foreign defendants. Firstly, the court analyzes the country's statute with a specific end goal to decide statutory existence for enabling the plaintiff to bring a case against the defendant in that state. Secondly, the court searches for activities exhibited by the defendant intentionally to his or her benefit of doing commercial activities in the that state. ${ }^{2}$ The second approach assumes an extensive part in the jurisdiction analytics, that is, "intentionally" and "sensibility".

Additionally, specific jurisdiction likewise can be inspected by two components; assessing jurisdiction is reliable with the prerequisites of "minimum contacts" and "reasonable play and significant equity". Determination of this can be from the fact that the foreign defendant has deliberately coordinated business activities or completed his transactions by which he intentionally profited. In this manner summoning the advantages and protection of its legal regulations; on the other hand, the case emerges from or identifies with the activities related to the defendant state and assessing jurisdiction is sensible. ${ }^{3}$

\section{U. S. Tests Employed in Assessing Jurisdiction in E-Commerce Disputes. \\ 3.1. Zippo Test}

In the Zippo case, the Court of Western Pennsylvania District developed the "minimum contact test" from the International Shoe case by expressing that jurisdiction for online organizations ought to be managed over a "sliding scale". ${ }^{4}$ Thus, the "minimum contacts" test puts forward the underlying procedure necessities which imply that a defendant, that is not domiciled in the place of business, must keep in mind the end goal to be liable to personal jurisdiction: "the defendant should have some particular minimum contracts attached to it to an extent that the adjudication of the suit does not breach 'customary notion of reasonable play and essential equity.' " ${ }^{5}$ Zippo Mfg. Co. v. Zippo Dot Com. Inc ${ }^{6}$ rising as though the original case on if a website gives the minimum contacts importance to assess jurisdiction. Zippo came out with a sliding scale approach to dissect the activities of the potential defendant made by websites in deciding the legality of practicing jurisdiction. The court concentrated on the "form and of the amount of activities that a company carried out over the Internet".?

\subsubsection{Categories of Zippo Test}

\section{a). Websites seen as active}

The defendant enters a contract agreement with a resident of a different legal system that includes the rehashed out-sending of computer documents online. ${ }^{8}$ The criteria for assessing jurisdiction is seen from this angle. As established in the zippo case, on the other hand of the "sliding scale" is "active sites", where the operator unquestionably transacts commercial activities online. However, regarding such, cases on jurisdiction are appropriate in light of the fact that the operator enters a contract agreement with a resident of a different legal system. This includes the knowledge and rehashed out-sending of process documents online, getting on-line requests and sending affirmation or other messages specifically to particular customers, and so forth.

A clear case of "active site" case was a pre-Zippo choice in CompuServe, Inc. v. Patterson. ${ }^{9}$ a Texas resident who happened to be the defendant transmitted software that could be downloaded for a fee to CompuServe's Ohio framework. Meanwhile, Patterson also conducted greater part of his advertising via CompuServe network system. ${ }^{10}$ CompuServe sold software that the defendant felt infringed his copyright and CompuServe brought a legal suit for declaratory judgment.

\section{b). Websites Seen as Passive.}

Passive sites just give information to an individual surfing the website. They might have gotten there via internet browsers, yet do not permit connection between the host of the site and a guest to the website. Passive sites do not transact business, offer products available to be purchased, or enable an individual surfing the site to purchase stock or to retrieve a file.

In this case, essential data in the form of information are posted online by the defendant whereby a user from foreign jurisdiction can get access to. This is not a ground for the assessing personal jurisdiction.

Mink v. AAAA Development, L.L.C. ${ }^{11}$ is a typical case that falls into this category. In Mink, the US Appeal Court for the Fifth Circuit found that the defendant's site, which had data about its goods and services was a

\footnotetext{
1 Burger King Corp. v. Rudzewicz, 471 U.S. 479, 105 S.Ct. 2185, 85 L. Ed. 2d 528 (1985).

World Wide Volkswagen v. Woodson, 444 U.S. 286 (1980), see also in Mitrani (2001), p.56.

3 Ballard v. Savage, 65 F.3d 1495, 1498 (9th Cir. 1995).

${ }^{4}$ See Zippo Mfg. Co. v. Zippo Dot Com, Inc., 952 F. Supp. 1119 (W. D. pa 1997), at 1124

Int'l Shoe Co. v. State of Wash., 326 U.S. 310 (1945).

${ }^{6}$ See Zippo Mfg. Co. v. Zippo Dot Com, Inc., 952 F. Supp. 1119 (W. D. pa 1997).

${ }^{7}$ See Zippo Mfg. Co. v. Zippo Dot Com, Inc., 952 F. Supp. 1119 (W. D. pa 1997), at 1124.

${ }^{8}$ CompuServe. Inc. v. Patterson, 89 F. 3d. 1267 (6th Cir. 1996).

${ }^{9}$ CompuServe, Inc. v. Patterson 89 F. 3d 1257 (6th Cir.1996), later cited as 'CompuServe”)

${ }^{10} \mathrm{Id}$.

${ }^{11}$ Mink v. AAAA Development, L.L.C 190 F.3d 333 (5th Cir. 1999)
} 
"passive" site in spite of the way that the site furnishes clients with a soft copy of mail in a different format, email address and without a toll number. ${ }^{1}$ The court noticed that the site of defendants was not sufficiently essential in assessing jurisdiction since the users could not buy through the sites.

\section{c). Websites seen as Interactive}

The center of the sliding scale is the interactive websites where a client can exchange data with the host computers. In this center scale, jurisdiction should be controlled by the "level of intelligence and business characteristic of trading of data that occurs on their site."2. Thus, internet business agreements can demonstrate an abnormal state of communication prompting the asserting of jurisdiction. In case the activities occurring is on the defendant's site of the scale is skewed towards the passive side, jurisdiction cannot be established. Except, in any case, the action side of the scale is skewed toward the active side, jurisdiction will probably be maintained. ${ }^{3}$

The middle category of Zippo case is the most problematic one. In spite of the fact that Zippo energizes appraisal of site interactivity, it failed to give a clear meaning of "interactivity". Some legal researchers have noticed this deficiency and a few district courts criticized Zippo for definitional equivocalness. ${ }^{4}$ The writers think if the Zippo test is aimed for advancing assurance in the peripheral cases, it failed to do as such, on the grounds that the broadness and unclearness of the "interactivity" definition will prompt conflicting outcomes in comparative truthful conditions.

The most created precept of jurisdiction according to the U.S is the Zippo sliding scale that empowers investigation about how the website is interactive taking into consideration its level. Be that as it may, It could be anticipated that the court would give a clear meaning of the term "interactivity", but did not. ${ }^{5}$ Besides, the Zippo test and the accentuation level on which the interactivity is inbuilt to the site turned out to be less important given that every single business webpage is now interactive at any rate exceedingly but indispensable to the advertising of the owners of sites. ${ }^{6}$

\subsection{Effects Test}

US courts as per jurisdictional development abroad, have additionally established an alternative way to deal with assessing jurisdiction in E- commerce disputes; an "effects" test, in view of the Court's judgement in Calder v. Jones. ${ }^{7}$ It grants states to assess jurisdiction if the defendant deliberately injured the residents at the forum. Practicing this "effects" test to online litigation, the courts of the U.S focuses around the genuine impacts the forum state derives from the website instead of endeavoring to look at the attributes of the web to decide the volume of agreement of the website associated with the state in which the suit is filed. ${ }^{8} \mathrm{Be}$ that as it may, an "effects" test will all the more effectively relate to damages in tort to people whereby damage is confined, or plan can be induced, but not with E-commerce cases including organizations. ${ }^{9}$ Since figuring where a bigger company with several outlet is "injured" is difficult to ascertain. ${ }^{10}$ The court noticed however that the "effects" test does not "have any significant bearing with a similar power" to a partnership as it does to an individual in light of the fact that an enterprise "do not endure injury in a specific topographical area in a similar situation of an individual." 11

\subsection{Targeting Test}

Scrutinizing the usage of the tests by Zippo and effects, certain courts in the U.S have concentrated on if there have been another special thing that is required for assessing jurisdiction in E-commerce cases. Courts additionally presented the "targeting test". ${ }^{12}$ The prerequisite that comes with this test is fulfilled whenever the defendant is accused to have taken part in some unlawful conducts that offend the offended litigant whom the offending litigant is aware to be domiciled in the state the suit is filed". ${ }^{13}$ Arguably the targeting-based test is a superior mechanism to be utilized by the court than the sliding scale test that comes with Zippo while assessing

\footnotetext{
${ }^{1}$ Id.

${ }^{2}$ See Zippo Mfg. Co. v. Zippo Dot Com, Inc., 952 F. Supp. 1119 (W. D. pa 1997), at 1124; see also

Maritz Inc. v. Cybergold Inc. 947 F Supp 1328 (ED Mo1996)

${ }^{3}$ See Zippo Mfg. Co. v. Zippo Dot Com, Inc., 952 F. Supp. 1119 (W. D. pa 1997), at 1124

${ }^{4}$ Michael Geist, (2001) AT 144.

${ }^{5}$ Boone (Spring 2006), p.241, 258.

${ }^{6}$ Rice (2004), p.11, 52

${ }^{7}$ Calder v. Jones, 465 U.S. 783 (1984), cited from Boone (Spring 2006), 241, 259-260. In Calder, a California resident sued in California Superior Court against Florida residents who supposedly

wrote false lies about her in a top national publication. In asserting jurisdiction, it was realized by the court that "the brunt of the harm, in terms both of respondent's emotional distress and the injury to her professional reputation, was suffered in California."

${ }^{8}$ Boone (Spring 2006), p.241, 260.

${ }^{9}$ Ibid.

${ }^{10}$ Rice \& Gladstone (2003), p.601, 629

${ }^{11}$ Cybersell, Inc. v. Cybersell, Inc., 130 F. 3d 414, 420 (9th Cir. 1997).

12 Bancroft \& Masters, Inc. v. Augusta Nat'1 Inc., 223 F. 3d 1082, 1087 (9th Cir. 2000)

13 Ibid.
} 
jurisdiction in E-commerce disputes litigations. The targeting test, unlike the Zippo test, places more noteworthy accentuation on distinguishing the goals of assessing or avoiding a specific jurisdiction. ${ }^{1}$ Going forward, the drafters of the targeting test portrayed it as a superior and more attractive mechanism that decides if the offending party sensibly foresaw that he or she is hauled into a court of the different legal system to respond in due order regarding the actions in the state with the absolutely different legal system. ${ }^{2}$

This assurance is vital to the due system examination clarified by the U.S Court in World-Wide Volkswagen: "The defendant's action and association with the State in which the suit has been filed to an extent that the party ought to sensibly foresee being hauled to legal proceeding. The Clause of the due process, by guaranteeing the 'efficient organization of the legal system, renders a level of consistency to the lawful framework that enables soon to be defendant to build their essential lead with some base certification with reference to where that action should not subject them to the suit." 3

Firstly, it depends on the defendant mindset: the defendant must "conduct" online business action in the state in which the suit is filed. Contrary to the approach by Zippo test, "a targeting investigation tries to distinguish the parties suppling mindset and to survey the means adopted to either assess or avoid a specific jurisdiction." This implies that a defendant particularly conducts its internet dealings at a discussion to be subject to jurisdiction of that country. ${ }^{4}$ This enabled the courts to have a strong reasonable premise: an "intended or planned activity" which is deem to handle advanced litigations and deliver reliable outcomes. ${ }^{5}$ On the second note, the defendant should expect to participate in commercial activities or different interaction in the state in which the suit is filed. On the third note, the defendant must take part in dealings that made a reason for activity as to an individual in the state in which the suit is filed.

As indicated by the three mechanisms above, the "targeting" mechanism renders an exclusive legitimate sureness over asserting jurisdiction in E-commerce disputes. This approach was proposed, and in addition, giving consistency and lawful conviction does not absolutely block the "American penchant for individualized equity". 6

\section{Defects of the U.S Practice to Assess Jurisdiction in E-commerce Disputes Resolution}

The basic defect of the practice by the U.S is the absence of predictability. Organizations have to elucidate if their websites achieve the height of interactivity that the courts will discover to get the job done for minimum contacts. Since legal choices are the main means with which organizations need to adopt, the early stages of online business imply that the two modern tests, Zippo Continuum and effects based, probably are not going to last indefinitely. Since the U.S depends on its non-governmental sector to determine the territory on what ought to and ought not to be controlled in the online business sector, ${ }^{7}$ legitimate guidelines are always in transition.

Again, assessing jurisdiction in E-commerce disputes can be problematic in the sense that regardless of whether any web action by anybody without business aim, missing the possibly predictable damage of trademark infringement would be adequate to determine jurisdiction over a foreign defendant. ${ }^{8}$ Regardless of whether a web user at one website making a report with a hyperlink into another's website would be adequate to assess jurisdiction over the owner of the connected site. ${ }^{9}$

\section{Conclusion}

From the discussion above, the internet has no topographical limits, which makes it difficult to determine jurisdiction in E-commerce disputes resolution. Additionally, given the endless manners by which contracting parties can cover up or mutilate individual or topographic information, there is no big surprise that internet obscurity postures particularly with reference to troublesome issues as a result of deciding the extent of "contract" with the foreseen forum state which the contract is under. ${ }^{10}$

The US have on a very basic level distinctive philosophical practice to dealing with jurisdiction in Ecommerce disputes resolution, though its legal framework grasps discretionary jurisprudence, following the International Shoe case, which centered around whether the defendant's actions form "minimum contacts" with a forum state, ${ }^{11}$ and also applying the sliding scale test from the Zippo case that recognizes three general classes of

\footnotetext{
${ }^{1}$ Michael GeistL, 1362 (2001) AT 144

${ }^{2}$ Ibid.

${ }^{3}$ World-Wide Volkswagen Corp. v. Woodson, 444 U.S. 286, 297 (1980).

${ }^{4}$ Aciman \& Vo-Verde (2002), 16, 19

${ }^{5}$ Boone (Spring 2006), p.241, 266.

6 Ibid.

${ }^{7}$ The White House, A Framework for Global Electronic Commerce (July 1, 1997).

${ }^{8}$ Digital Equipment Corporation v. Altavista Technology, Inc., Civ. Action 96-12192 NG

${ }^{9}$ Playboy Enterprises, Inc. v. Frene, 839 F.Supp. 1552 (M.D. Fla. 1993).

${ }^{10}$ Boone (Spring 2006), p.241, p.273.

${ }^{11}$ International Shoe Co. V. Washington, 326 U.S 310 (1945).
} 
sites in light of their intuitive and business attributes. ${ }^{1}$

The defects of the US practice to assess jurisdiction in E-commerce disputes resolution can be filled by bilateral or multilateral assertions; by learning from other country's jurisdictional approach, or by modernizing and harmonizing international, regional and national standards from other country's past encounters and practices.

\section{References:}

1. Aciman, C. \& Vo-Verde, D. (2002) "Refining the Zippo Test: New Trends on Personal Jurisdiction for Internet Activities", Computer \& internet Law, 19:16.

2. Boone, B. D. (Spring 2006) Bullseye! "Why a "Targeting" Approach to Personal Jurisdiction in the Ecommerce Context Makes Sense Internationally”, 20 Emory Int'l L. Rev. 241.

3. Cordera, M. 1. (2001) "E-Consumer Protection: A Comparative Analysis of EU and US Consumer Protection on the Internet”, 27 Rutgers Computer \& Tech. L.J. 231, 237.

4. Geist, M. (2001) "Internet Law in Canada" 69,2d ed.

5. Geist, M. (2001) "Is There a There There? Towards Greater Certainty for Internet Jurisdiction",.

6. Maloney, M. (1993) "Specific Jurisdiction and the "Arise from or Relate to" Requirement... What Does It Mean? 50 Wash. \& Lee. L. Rev. 1265.

7. Mann, R. J (2008) "Electronic commerce", Wolters Kluwer, Law and Business: Aspen publisher (3rd edition) PLI/PAT 661:5, 575/ Berkeley Tech. L.J. 16: 1345.

8. Praveen, K. M. "Emerging Trends Of E-Consumers \& Determining Jurisdictional Disputes in India": International Journal of Legal Insight, Volume I, Issue 1 | Issn: 2456-3595.

9. Restatement, Second, Conflict of Laws $§ 30$ (1971).

10. Rice, D. T. \& Gladstone, J. (2003) "An Assessment of the Effects Test in Determining Personal Jurisdiction in Cyberspace", 58 Bus. Law. 601.

11. Rice, D. T. (2004) "Problems in Running a Global Internet Business: Complying with the Laws of Other Countries", (2004) 797 PLI/PAT 11, 52.

12. Scoles, E. F., Hay, P., Borchers, P. J. \& Symeonides, S.C. (2000) “Conflict of Laws”, St. Paul. Minn: West Group, 3rd Ed.

13. Smith, G. J. H. (2002) "Internet Law and Regulation", London: Sweet \& Maxwell, 3th ed.

14. Turban. E. king D. McKay J. Marshall P. Lee J. and Viehland D. (2008) "Electronic Commerce: A managerial Perspective". Prentice Hall, (5 ed.).

15. Wang, F. F. (2008) "Obstacles and Solutions to Internet Jurisdiction: A Comparative Analysis of the EU and US laws". Journal of International Commercial Law and Technology, Vol. 3, Issue 4.

\footnotetext{
${ }^{1}$ Zippo Manufacturing Co. V. Zippo Dot Com, Inc.., 952 F. Supp. 1119 (W. D. Pa. 1997).
} 